\title{
Eksistensi Hak Ulayat Dalam Masyarakat Hukum Adat
}

\author{
Umar Hasan, Suhermi, Sasmiar \\ Fakultas Hukum, Universitas Jambi, Indonesia
}

\begin{abstract}
ABSTRAK
Undang-Undang Dasar 1945 mengakui adanya masyarakat adat beserta hak-haknya sebagaimana diatur pada pasal 18B, yaitu; 1) Negara mengakui dan menghormati satuan-satuan pemerintahan daerah yang bersifat khusus atau bersifat istimewa yang diatur dengan undang-undang. 2) Negara mengakui dan menghormati kesatuan-kesatuan masyarakat hukum adat beserta hak-hak tradisionalnya sepanjang masih hisup dan sesuai dengan perkembangan masyarakat dan prinsip Negara Kesatuan Republik Indonesia, yang diatur dalam undang-undang. Pengolahan, pemanfaatan, dan penggunanan isi/obyek dari hak ulayat ditujukan untuk persekutuan dan anggota masyarakat adat dengan dipimpin oleh ketua persekutuan. Namun kenyataannya sekarang ini tanah hak ulayat yang ada di beberapa wilayah Indonesia sudah mulai melemahkan walaupun hak ulayat atau hak purba di tempat lain ada juga yang masih kuat. Dan gejala yang bersifat umum, semakin maju dan bebasnya penduduk dalam usaha-usaha pertaniannya, semakin lemahlah hak ulayat/hak purba itu dengan sendirinya. Akhirnya jika hak ulayat sudah lemah sama sekali, maka dengan sendirinya hak perseorangan akan berkembang dengan pesatnya. Maka permasalahan yang akan dirusmuskan dalam penelitian ini adalah sebagai berikut: 1 . Bagaimanakah eksistensi hak ulayat dalam masyarakat adat di Indonsia pada saat sekarang 2. Apa sajakah faktor penyebab melemahnya hak komunal menjadi hak milik perseorangan? Tipe penelitian yang digunakan adalah yuridis empiris. Penelitian ini menggunakan data lapangan sebagai data primer dan data skunder yang diperoleh melalui perpustakaan yang terdiri dari peraturan, jurnal dan lain-lain. Hasil penelitian menunjukkan bahwa Eksistensi hak ulayat dalam masyarakat hukum adat di Provinsi Jambi pada saat ini khususnya di Kabupaten Merangin, Kota Sungai Penuh dan Kabupaten Bungo sudah mulai melemah. Faktor penyebab melemahnya hak ulayat menjadi hak milik perseorangan adalah: Faktor masyarakat itu sendiri dan faktor kebijakan Pemerintah
\end{abstract}

Kata Kunci: Eksistensi, hak ulayat, hukum adat

\section{PENDAHULUAN}

Tanah sangat dibutuhkan oleh semua orang, karena mulai dilahirkan sampai dengan meninggal dunia memerlukan tanah. Kebutuhan akan tanah mulai terlihat dengan adanya perkembangn manusia yang semakin cepat, sementara tanah tidak bertambah. Oleh karena itu tanah merupakan investasi yang sangat dibutuhkan sesuai dengan perkembangan dari waktu ke waktu.

Manusia dengan tanah mempunyai hubungan yang mendasar karena pemilikan dan penggunaan tanah dapat dipergunakan untuk kehidupan baik untuk kelompok maupun untuk perseorangan. Setelah tanah dikuasai, setiap orang berusaha agar tanah tersebut tetap dipertahankan, bahkan berusaha agar tanah tersebut tetap dikuasai dan ingin memiliki tanah semakin banyak lagi. 
Menurut Tolib Setiady $(2013,311)$ Tanah merupakan benda kekayaan yang yang tidak bergerak dan mempunyai nilai yang sangat penting pada masyarakat hukum adat. Di samping itu sebagai tempat kediaman, dan tempat mencari nafkah bagi persekutuan, serta untuk tempat dimakamkan.

Pengaturan tentang pengguasaan, pemilikan, penggunaan, dan pemanfaatan tanah diatur dalam suatu aturan. Sebelum berlakunya undang-undang tersebut, ketentuan tentang pertanahan yang berlaku di Indonesia bersifat dualistis. Akibatnya terdapat hukum tanah barat dan hukum tanah adat.. Pengakuan hak ulayat atau hak komunal secara resmi dalam Undang-Undang telah dilakukan pada zaman Hindia Belanda, walaupun hak ulayat pada kenyataannya terdapat dalam masyarakat hukum adat.

Pengakuan keberadaan masyarakat hukum adat beserta hak-haknya terdapat pada Pasal 18 B Undang-Undang dasar 1945 dan Pasal 3 UUPA yang menyatakan bahwa Negara mengakui dan menghormati kesatuan-kesatuan msyarakat hukum adatnya beserta hak tradisionalnya sepanjang masih ada. Undang-Undang Hak asasi manusia menentukan bahwa indentitas budaya masyarakat tradisional dihormati selaras dengan perkembangan zaman dan peradaban.

Menurut AP. Parlindungan (1998,93), Hak ulayat pada saat ini masih diakui, berfungsi, dan dipatuhi sebagai lembaga dalam masyarakat, akan tetapi keberadaannya harus disesuaikan dengan kepentingan nasional, Negara, dan Bangsa Indonesia.

Menurut Hayatul Ismi dalam Jurnal Ilmu Hukum ( 2012), menjelaskan bahwa keberadaan masyarakat hukum adat beserta hak tradisional tergantung dengan syarat yang diberikan oleh Negara yang diatur dalam Undang-Undang.. Hal ini menunjukkan bahwa hukum Negara lebih superior dibandingkan hukum adat, seharusnya hukum adat sejajar dengan Undang-Undang, sehingga memberikan alternatif bagi masyarakat hukum adat maupun pihak luar untuk melakukan pilihan hukum ketika terjadi hubungan hukum yang mengatur kepentingan mereka.

Hak komunal sampai saat ini masih diterima dan dijunjung dalam aturan yang berlaku dengan syarat hak tersebut masih terdapat dalam masyarakat kaum. Sumber daya alam yang merupakan bagian dari hak komunal atau hak kaum dapat dipergunakan untuk kemakmuran warganya, oleh karena itu hak tersebut perlu dilestarikan dengan baik sehingga warga kaum bisa menikmati untuk keperluan hidup mereka.

Pengakuan hak purba harus memenuhi syarat, yaitu eksistensi dan pelaksanaannya. Pengakuan keberadaannya jika memang masih ada pada masyarakat tersebut, kemudian pelaksanaannya tidak bentrok dengan keperluan bangsa. Hak purba atau komunal merupakan kewenangan warganya atas wilayah tertentu untuk mengambil manfaatnya termasuk daratan untuk menjalani kehidupanya baik secara jasmani maupun rohani dari zaman dahulu dan tidak 
pernah terhenti antara daerah kehidupannya dengan masyarakat hukum adat tersebut

Menurut Nova Yarsina dalam jurnal Cendiaka Hukum (2018), Pemahaman masyarakat mengenai hak ulayat belum merata dipahamai oleh sebagian masyarakat dan pejabat pemerintah, sehingga sering menimbulkan perbedaan pendapat mengenai status tanah ulayat

Berdasarkan Peraturan Menteri Agraria tentang Pedoman Penyelesaian Masalah Hak Ulayat, ditentukan bahwa:

1) Ketentuan hukum adat setempat sangat menentukan dalam pelaksannaan hak ulayat

2) Hak ulayat masyarakat hukum adat dianggap masih ada apabila ketentuan hukum adat masih diakui dan dilaksanakan dan ditaati oleh setiap orang sebagai warga persekutuan hukum adat tersebut. Untuk menjalani kehidupan dan memenuhi kebutuhan hidup sehari hari dilakukan pada tanah ulayat mereka. Mengenai pengurusan, penguasaan dan penggunaan tanah ulayat yang berlaku diatur berdasarkan tatanan hukum adatnya. Pengakuan hak ulayat dilakukan jika menurut kenyataannya masih ada yaitu jika terdapat segolongan orang yang terikat pada tatanan hukum adatnya.

Hak untuk menggarap bumi, telaga, empang dan pinggir laut serta mencari hewan yang hidup bebas dalam rimba merupakam hak anggota kaum atas tanah komunalnya.( Ter Haar 1980: 69).

Hak ulayat terdiri dari:

1. Bumi

2. Perairan seperti sungai, danau, tepi laut

3. Tanaman yang hidup secara liar

4. Hewan yang hidup bebas dalam rimba

Hak ulayat yang dimiliki sebuah kelompok dapat diolah oleh anggota kaum itu sendiri atau yang bukan anggota kaumnya untuk dijadikan sebagai tempat mata pencaharian termasuk memanfaatkan tanaman dan hewan yang hidup bebas dalam tanah kaum tersebut. Anggota kaum dan kepala adat berperan terhadap warga yang bukan anggota kaum yang melakukan pelanggaran. (Djaren Saragih, !978,77)

Hak ulayat menjadi sumber hak individual baik secara langsung maupun tidak langsung. Pergeseranan gaya hidup ke gaya yang modren dari gaya yang tradisional mengakibat secara pelan-pelan prinsip-prinsip yang terdapat dalam hak ulayat yang awalnya dikuasai dan dimiliki oleh masyarakat adat untuk dimanfaatkan secara bersama-sama demi kepentingan persekutuan beralih menjadi kepemilikan pribadi dan didaftarkan atas nama pribadi.

Pada dasarnya dalam hak ulayat ini juga terdapat hak perseorangan. Hak persekutuan hukum (hak ulayat) atas tanah dengan hak perseorangan atas tanah mempunyai hubungan yang sangat erat dan saling mempengaruhi satu sama lain (Bambang Daru Nugroho, 2015,155). Hak perseorangan atas tanah meliputi hak 
untuk mengambil hasil rimba, umpamanya damar, menangkap hewan, memanfaatkan tanaman yang tumbuh dan lain-lain. Jika tanah tersebut diolah, digunakan dan diambil keuntungan sepanjang waktu oleh kaum yang menetapkan di tanah kaumnya tersebut maka anggota tersebut tidak boleh merugikan pihak lain. Dengan menguasai dan menggunakan sepanjang waktu maka akan terjadi hak individual dan hak kaum berangsur-angsur menghilang sebaliknya jika tanah tersebut diterlantarkan maka hak kaum akan muncul kembali dan hak individual akan menghilang. Dalam persekutuan hukum atau masyarakat adat dikenal adanya hak tanah perseorangan dan hak tanah masyarakat hukum adat (hak ulayat), kedua hal ini saling pengaruh mempengaruhi yang terkenal dengan teori bola yang dikemukan oleh Teer Haar atau terjadi hubungan kempis- mengembang, desak mendesak, batas membatasi, di mana hak ulayat kuat di situ hak perseoranga melemah demikian pula sebaliknya(Soerojo Wignyodipuro, 1978,239). Hubungan yang bersifak kempis mengembang ini berlangsung terus tanpa henti, dan hubungan tersebut dapat mengakibatkan kuat atau melemahnya keberadaan hak ulayat dalam masyarakat Indonesia.

Pengolahan, pemanfaatan, dan penggunanan isi/obyek dari hak ulayat ditujukan untuk persekutuan dan anggota masyarakat adat dengan dipimpin oleh ketua persekutuan. Namun kenyataannya sekarang ini tanah hak ulayat yang ada di beberapa wilayah Indonesia sudah mulai melemah karena disebabkan beberapa faktor salah satunya perkembangan pembangunan dibidang perkebunan yang dilakukan oleh pengusaha. Pada kenyataannya sering terdapat perbedaan persefsi tentang keberadaan hak ulayat antara masyarakat, pengusaha khususnya pengusaha perkebunan dan penguasa. Untuk itu penting dilakukan penelitian agar eksistensi hak purba tetap dapat dipertahankan keberadaannya dan dilindungi.

Berdasarkan paparan di atas maka peneliti tertarik untuk mengetahui tentang eksistensi tanah hak ulayat di Propinsi Jambi khususnya di daerah Kabupaten Merangin, Kabupaten Bungo dan Sungai Penuh.

\section{Perumusan Masalah}

1. Bagaimana eksistensi hak ulayat dalam masyarakat adat di Propinsi Jambi pada saat sekarang

2. Apa sajakah faktor penyebab melemahnya hak komunal menjadi hak milik perseorangan?

\section{METODE PENELITIAN}

Untuk telaah kasus eksistensi hak ulayat dilakukan di Provinsi Jambi dengan fokus lokasi kegiatan di Kota Sungai Penuh, Kabupaten Bungo dan Kabupaten Merangin.P enelitian ini merupakan penelitian non doktrinal atau penelitian Yuridis Empiris. Dimana penelitian ini dilakukan secara langsung kepada narasumber dan 
informan untuk memperoleh data primer sebagai data utamnaya disamping data skunder (bahan hukum).

\section{PEMBAHASAN}

\section{Eksistensi Hak Ulayat dalam Masyarakat Hukum Adat}

Keberadaan hak ulayat dalam masyarakat hukum adat di Indonesia pada saat sekarang tidak sama antara satu dengan yang lainnya. Ada wilayah persekutuan hukum adat yang hak ulayatnya masih dijalankan dan berpengaruh dalam kehidupan masyarakatnya tetapi ada juga wilayah daerah yang karena menguatnya sifat individualistis dan masyarakat dan melemahnya sifat komunalistis menjadikan hak ulayat itu tidak berlaku sepenuhnya atau memudar bahkan hilang dalam kehidupan masyarakat.

Penjelasan Pasal 67 Ayat (1) Undang-Undang Nomor 41 Tahun 1999 tentang Kehutanan mengatur tentang bahwa masyarakat hukum adat keberadaannya, jika menurut kenyataannya mememnuhi unsur antara lain:

a. Masyarakatnya masih dalam bentuk paguyuban

b. Ada kelembagaan dalam bentuk perangkat penguasa adatnya

c. Ada wilayah hukum adatnya yang jelas

d. Ada pranata dan perangkat hukum, khususnya peradilan, yang masih ditaati dan masih mengadakan pemungutan hasil hutan di wilayah hutan sekitarnya untuk pemenuhan kebutuhan hidup sehari-hari.

Seiring dengan perkembangan zaman, maka pergerakan pola hidup dan corak hidup masyarakat Indonesia dari semula tradisional menuju ke pola atau corak modern yang mengakibatkan secara berlahan-lahan nilai yang terkandung dalam hak ulayat menjadi bergeser. Hal tersebut menjadikan masyarakat tidak lagi mendepankan kebersamaan tetapi cenderung untuk berpikir individualistis, sehingga banyak hak ulayat masyarakat hukum adat yang awalnya dikuasai dan dimiliki oleh msyarakat hukum adat untuk dimanfaatkan secara bersama-sama demi kepentingan persekutuan beralih menjadi kepemilikan pribadi dan didaftarkan atas nama pribadi.

Berdasarkan hasil penelitian tentang hak ulayat di Kabupaten Merangin khususnya di Desa Selango yang dikenal dengan Margo Tiang Pumpung yang termasuk ke dalam hukum adat Luak XVI, hak ulayat yang seharusnya dipergunakan untuk kepentingan bersama masyarakat adat dengan adanya warga pendatang yang tinggal dan melakukan perkawinan dengan masyarakat asli di marga Tiang Pumpung sehingga terjadi percampuran kebudayaan sehingga berpengaruh pad keaslian pola kehidupan masyarakat persekutuan hukum adat Tiang Pumpung, hal ini menyebabkan melemahnya ikatan ulayat antara masyarakat persekutuannya. Keadaan ini yang menyebabkan masyarakat adat Tiang Pumpung menjadi semakin pudar keberadaannya, sehingga tidak dapat dikatakan bahwa 
masyarakat persekutuan hukum adat bahwa masyarakat persekutuan hukum adat Margo Tiang Pumpung secara utuh masih ada.

Di samping hal tersebut di atas, persekutuan adat Tiang Pumpung Kecamatan Muaro Siau mempunyai wilayah adat atau hak ulayat yang oleh masyarakat setempat dikenal dengan sebutan tanah Margo yang batas-batasnya ditentukan berdasarkan batas-batas alam yang telah diturunkan secara turun temurun. Sama halnya dengan persekutuan adat lainnya di Indonesia hak ulayat dalam persekutuan adat Tiang Pumpung juga diperuntukkan untuk kepentingan bersama anggota masyarakat, dimana setiap masyarakat yang membutuhkan tanah dapat menggunakan tanah ulayat untuk tempat tinggal atau untuk bercocok tanam dengan menggunakan tanah ulayat dengan mengikuti aturan-aturan adat dalam persekutuan adat Tiang Pumpung, sehingga lama kelamaan tanah yang dahulunya berstatus tanah hak ulayat yang diperuntukan untuk masyarakat bersama beralih menjadi tanah pribadi masyarakat yang didaftarkan hingga memiliki surat bukti kepemilikan tanahnya. Perubahan seperti ini menyebabkan wilayah ulayat persekutuan hukum adat Tiang Pumpung menjadi hilang.

Dengan terjadinya perubahan dari wilayah persekutuan hukum adat menjadisatu Kecamatan setelah berlakunya Undang-Undang Nomor 5 Tahun 1979 tentang Pemerintahan Desa peran dari penguasa adat menjadi berkurang karena berbenturan dengan peran pemerintah setempat. Tugas dan wewenang Pesirah Kepala Marga yang dahulunya menentukan seberapa besar bagian wilayah dan lo

kasi wilayah tanah ulayat sekarang hanya terbatas pada pengaturan upacara adat, sebutan pesirah kepala marga setelah keluarnya keluarnya undang-undang ini berubah menjadi kepala adat. Menurut Bambamg Nugroho $(2015,93)$ Sejak diberlakunya Undang-Undang Pemerintahan Desa, hamper dipastikan pemerintah adat satu demi satu mengalami pergeseran pola dan sistemnya, meskipun secara normatif hukum Adat tetapi hamper tidak ada lembaga masyarakat adat yang legitimatif untuk melaksanakannya.

Untuk kepentingan pembangunan, tanah yang berstatus hak milik maupun tanah ulayat sering ikut dikorbankan. Keinginan untuk meningkatkan kesejahteraan pribadi, keluarga, dan masyarakat yang diwujudkan dalam suatu pembangunan menyebabkan peningkatan kebutuhan atas tanah, sedangkan ketersediaan atas tanah terbatas. Kurangnya ketersediaan atas tanah untuk pembangunan menyebabkan pemerintah melakukan pembebasan tanah atas tanah termasuk hak ulyat.

Hal ini juga terjadi di Kota Sungai Penuh, Pembangunan diberbagai sektor begitu terasa di Kota Sungai, salah satunya adalah pembangunan perkantoran dan tempat bersejarah. Pembangunan Museum Maliki Air dilakukan untuk kepentinangan pembangunan khususnya untuk kepentingan perkembangan kamajuan kota di bangun di atas tanah ulayat. 
Para pemangku adat menyatakan dalam proses penyerahan tanah ulayat harus sesuai dengan ketentuan adat yang berlaku. Menurut hukum adat penyerahan tanah ulayat untuk keperluan pembangunan dilakukan dengan duduk bersama dan mengajun arah (izin membangun) bersama pemangku adat.

Menurut Kisran Rachim, selaku Sekretaris Lembaga Kerapat Adat mengatakan bahwa; Lahan dan yang digunakan untuk kepentingan pembangunan museum di desa Maliki air Hamparan rawang merupakan bagian territorial hukum adat Keinci yang menganut sistem kepimilikan tanah secara komunal atau lebih dikenal dengan sebutan tanah hak ulayat. Oleh karena itu tanah yang terdapat di daerah ini pada prinsipnya adalah tanah ulayat kemudian dalam perkembangannya ada dilepas untuk kepentingan pembangunan.

Pembangunan museum Adat Kota Sungai penuh tidak melibatkan para pemangku adat Depati IV-8 Helai Kain. Pemerintah Kota Sungai Penuh dan panitia tidak melakukan duduk bersama para pemangku adat se alam Kerinci, sebelum duduk dengan depati helai IV-8 kain termasuk dengan pengurus lembaga kerapatan adat se alam Kerinci.. Hal ini menyebabkan pemangkua adat merasa tidak dihargai oleh Pemerintah Kota Sungai Penuh.

Eksistensi hak ulayat akan dipertaruhkan apabila menyangkut dengan hak menguasai masyarakat hukum adat atas wilayahnya, sebagian besar terjadi dalam usaha perkebunan dalam rangka investasi. Kegiatan investasi tidak bisa lepas dengan faktor produksi salah satunya adalah tanah. Dalam kegiatan investasi pemakaian tanah untuk keperluan hak guna usaha, hak guna bangunan dan hak pakai. Peran Negara sangat penting untuk mencegah terjadinya konflik dan kegiatan investasi tersebut dapat membawa dampak positif bagi masyarakat .

Pelaku usaha perkebunan dapat diberi hak dalam hal tanah yang diperlukan untuk usaha perkebunan merupakan tanah ulayat masyarakat hukum adat, pelaku usaha perkebunan harus melakukan musyawarah dengan masyarakat hukum adat pemegang hak untuk memperoleh persetujuan mengenai penyerahan tanah dan imbalannnya. Jika belum tercapai persetujuan, maka pejabat yang berwenang dilarang memberikan izin usaha di atas tanah ulayat masyarakat hukum adat.

Di Kabupaten Bungo, Berdasarkan SK Menhut Nomor 863/Menhut-II/ 2014 tanggal 14 September 2014 terdapat total luas kawasan hutan 149. 336,92 hektar.

Hutan berdasarkan statusnya dibedakan menjadi dua, yaitu:

1.Hutan Negara

2. Hutan hak. Adapun hutan hak dibedakan atas, hutan adat (hak ulayat) dan hutan perseorang/badan hukum.

Menurut Pasal 1 Angka 6 Undang-Undang Nomor 41 Tahun 1999 tentang Kehutanan, hutan adat adalah hutan negara yang berada dalam wilayah masyarakat hukum adat. Berdasarkan Putusan MK Nomor 35/PUU-X/2012, hutan 
adat adalah hutan yang berada di wilayah masyarakat hukum adat, sehingga hutan Negara tidak termasuk hutan adat. Dengan Putusan MK ini masyarakat hukum adat dapat memperoleh haknya yang dijamin konsitustusi "pengelolan hutan adat ditangan masyarakat adat" namun bukan berari masyarakat hukum adat berhak mengelola hutannya tanpa ada aturan dari pemerintah (Kementerian Kehutanan).

Perkembangan perkebunan sawit yang menggunakan hutan adat/hak ulayat terjadi di beberapa daerah. Pemerintah atas nama alat negara mengambil alih hak kesatuan masyarakat adat, hutan adat diserahkan kepada inverstor untuk usaha perkebunan tanpa memperhatikan hak masyarakat adat di wilayah tersebut. Hal ini juga terjadi di Kabupaten Bungo.

Berdasarkan data dari Dinas Kabupaten Bungo, Hutan adat di Kabupaten Bungo terdiri dari:

1. Hutan Adat Batu Kerbau Dusun Batu Kerbau Kecamatan Pelepat seluas 386 hektar (Dasar SK Bupati Bungo Nomor 1249 Tahun 2002 tanggal 16 Juli 2002) serta dipertegas dengan SK Menteri Lingkungan Hidup dan Kehutanan Nomor SK 5254/MENLHK-PSKL/ PKTHA/PSL.1/10/2017 tanggal 11 Oktober 2017.

2. Hutan adat Kampung Belukar Panjang Dusu Batu Kerbau Kecamatan Pelepat seluas 472 hektar (Dasar SK Bupati Bungo Nomor 1249 Tahun 2002 tanggal 16 Juli 2002

3. Hutan Adat Kampung Lubuk Tebat Dusun Batu Kerbau Kecamatan Pelepat seluas 360 hektar (Dasar SK Bupati Bungo Nomor 1249 tanggal 16 Juli Tahun 2002)

4. Hutan Adat Baru Pelepat Kecamatan Pelepat seluas 780 hektar (Dasar Peraturan Daerah Kabupaten Bungo Nomor 3 Tahun 2006 tanggal 17 Oktober 2006) serta dipertegas dengan SK Menteri Lingkungan Hidup dan Kehutanan Nomor SK.5531/MENLHK.PSKL/ PKTHA/ PSL.11/10/2017 tanggal 23 Oktober 2017

5. Hutan Adat Bukit Bujang Dusun Senamat Ulu Kecamatan Bathin III Ulu, seluas 223,69 hektar ( Dasar SK Bupati Bungo Nomor 48/Hutbun Tahun 2009 tanggal 10 Februari 2009 serta dipertegas dengan SK Menteri Lingkungan Hidup dan Kehutanan Nomor SK. 5255/MENLHK-PSKL/PKTHA/PSL.1/10/2017 tanggal 11 Oktober 2017

6. Hutan Adat Rimbo Bulim Masyarakat Bathin Uleh Kecamatan Tanah Tumbuh seluas 40,68 hektar (Dasar SK Bupati Kabupaten Bungo Nomor 528/Hutbun Tahun 2010 tanggal 05 November 2010) serta dipertegas dengan SK Menteri Lingkungan Hidup dan Kehutanan Nomor SK 775/MENLHKPSKL/PKTHA/PSL.1/2/2018

Berdasarkan Undang Undang Kehutanan pelaku usaha perkebunan dapat diberi hak dalam hal tanah yang diperlukan untuk usaha perkebunan merupakan tanah ulayat masyarakat hukum adat. Dengan ketentuan pelaku usaha perkebunan 
terlebih dahulu harus melakukan musyawarah dengan masyarakat hukum adat pemegang hak untuk memperoleh persetujuan mengenai penyerahan tanah dan imbalannnya. Jika belum tercapai persetujuan, maka pejabat yang berwenang dilarang memberikan iin usaha di atas tanah ulayat masyarakat hukum adat.

Berdasarkan hasil penelitian di Kabupaten Bungo pembukaan lahan perkebunan oleh pihak investor baik nasional, maupun asing langsung melalui Bupati dengan dinas terkait yang berkuasa pada saat itu. Investor tidak pernah menemui masyarakat hukum adat atau Rio (sebutan Kepala Desa), ditambah lagi kondisi masyarakat hukum adatnya sudah mulai terkikis akibat pengaruh modrenisasi dan globalisasi. Yang penting bagi mereka jangan menggangu lahan pertanian (fatlah) dan lahan perkebunan (halkah) milik individu masyarakat. Akan tetapi jika lahan mereka dalam bentuk fatlah dan halkan tersebut diambil untuk lahan perkebunan swasta/negara mereka baru minta ganti kerugian sesuai dengan harga pasaran/Nilai Jual Objek Pajak (NJOP) saat itu.

Dengan terkikisnya nilai masyarakat hukum adat setempat, tentu akan mempengaruhi kepedulian mereka terhadap konsep kepemilikan hak ulayat. Perlu dikatahui dalam sistem pemerintahan Rio di Kabupaten Bungo, semua wilayah atau tanah di luar fatlah dan halkah pribadi, itu merupakan wilayah/tanah "Bathin" atau hak ulayat. (wawancara dengan Datuk Mahmud, Ketua Lembaga Aadat Melayu Kabupaten Bungo,2020).

Jadi semua lahan perkebunan, pertambangan batu bara yang berasal dari tanah Bathin (hak ulayat) investor mendapatlkan persetujuan langsung dari Bupati yang berkuasa pada saat itu, masyarakat hukum adat tidak pernah dilibatkan. Selain itu semua tanah Bathin yang ada di wilayah Kabupaten Bungo tidak terdata dengan pasti berapa luasnya, dan tidak ada legalitas dari pemerintah seperti Peraturan Daerah untuk penentuan tanah bathin tersebut. Pemerintah menganggap semua wilayah/tanah di luar fatlah dan halkah adalah merupakan tanah negara yang dikuasai oleh negara, keccuali wilayah " Hutan Adat Datuk Sinaro Putih "Dusun (desa) Baru Pelepat yang sudah ditetapkan dengan Perda Kabupaten Bungo No.8 Tahun 2012 tentang Kawasan Hutan Adat Dusun Baru Pelepat, dan Keputusan Menhut Nomor SK.727/Menhut-II/2012 tanggal 12 Desember 2012.

Pada hal kawas hutan yang diatur dalam Pasal 18 B, 28 I dan 23 yang dipertegas dengan Tap MPR RI No.IX 2001 dan Kepres No.111 Tahun 1999, yang memutuskan bahwa hutan adat bukan lagi masuk hutan negara, tetapi menjadi “ Hutan Hak " yang diperkuat oleh Keputusan Mahkamah Konstitusi N0.35/PUU$\mathrm{X} / 2012$.

Berdasarkan data dari Badan Perencanaan Pembangunan Daerah (Bappeda) dan Biro Pusat Statistik (BPS) tahun 2003, Kabupaten Bungo memiliki luas wilayah $4.659 \mathrm{~km}$ dengan jumlah panduduk sebesar 332.881 jiwa dengan sebaran penduduk 71 jiwa/km. Secara Administratif Kabupaten Bungo berbatasan dengan : 
- Sebelah Utara berbatas dengan Kabupaten Dharmas Raya (Sumbar) .

- Sebelah Selatan berbatasan dengan Kabupaten Merangin.

- Sebelah Barat berbatasan dengan Kabupaten Kerinci.

- Sebelah Timur berbatasan dengan Kabupaten Tebo.

Dari luas tersebut terdapat 71.700 ha. Merupakan wilayah TNKS yang ada di Kabupaten Bungo,

Penggunan tanah ulayat untuk perkebunan selain diperlukan persetujuan dari masyarakat hokum adat memungkinkan masyarakat hokum adat untuk mendapatkan imbalan. Namun berdasarkan hasil penelitian, Sepanjang diketahui belum pernah masyarakat hukum adat menerima kompensasi baik dari investor maupun dari pemerintah atas pembebasan hak ulayat untuk perkebunan, kecuali pembebasan tanah tersebut berasal dari fatlah dan halkah masyarakat secara individu, baru mendapat kompensasi ganti kerugian. Jadi pemerintah menetapkan setiap tanah/wilayah yang bukan fatla dan halkah pribadi masyarakat, itu merupakan tanah negara, walaupun tanah tersebut merupakan tanah bathin (tanah hak ulayat) masyarakat hukum adat.

Pemanafaaat tanah ulayat oleh pihak invertor, sebaiknya memberikan manfaat terhadap masyarakat hukum adat tersebut, Manfaat secara langsung tidak ada, akan tetapi secara tidak langsung masih ada manfaat bagi masyarakat dengan berdirinya perkebunan swasta tersebut, seperti penyerapan tenaga kerja, penerimaan CSR dari perusahaan untuk membangun/memeperbaiki fasilitas umum seperti tempat ibadah, jalan dan lain-lainnya. Kemudian terbukanya akses jalan dengan berdirinya perkebunan tersebut yang membawa dampak terhadap perkembangan ekonomi masyarakat. Dengan dibukanya perkebunan tersebut masyarakat banyak yang berjualan untuk pemenuhan kebutuhan hidup sehari-hari, munculnya sarana pengangngkutan seperti ojek, angkutan umum roda empat dan lain-lain. Menurut Djuhaendah Hasan $(2007,16)$, dalam dunia usaha penggelolaan perusahaan, keberhasi;an suatu usaha selain keuntungan yang diperoleh juga meliputi keperdulian perusahaan terhadap masyarakat dan lingkungannya dalam bentuk tanggung jawab sosial perusahaan (CSR/Corporate Social Responsibiliy)

Berdasarkan hasil penelitian, bahwa keberadaan hak ulayat di tiga lokasi penelitian meninjukkan adanya indikasi kearah melemahnya hak ulayat yang disebabkan antara lain berkurangnya tanah yang digunakan untuk perkebunan dan peranan ketua adat yang berfungsi dan masuknya pendatang yang mengakibatkan terjadinya percampuran kebudayaan sehingga melemahkan tanah ulayat tersebut.

\section{Faktor Melemahnya Eksistensinya Hak Ulayat}

\section{Internal}

Kultur masyarakat mulai berubah dengan adanya pengaruh globalisasi saat ini, masyarakat sudah mulai meninggalkan cara-cara lama yang bersifat kepentingan 
bersama (hak komunal) dalam mempertahankan hak atas tanah bathin, dengan demikian pengakuan terhadap tanah bathin ini sudah mulai melemah.

Selain itu, makin menguatnya pengakuan terhadap hak individu atas fatlah dan halkan, dengan cara (mendaku) hutan yang sebenarnya wilayah tanah bathin, dan memproses menjadi penguasaan/kepemilikan tanah hak milik (pribadi). Ketentuan dalam Perundang-Undangan menyatakan bahwa apabila seseorang telah menguasai suatu tanah/wilayah selama 20 tahun berturut-turut tanpa ada protes dari pihak lain mka mereka memproses hak atas tanah tersebut menjadi hak milik pribadi

\section{Eksternal}

Adanya kebijakan Pemerintah yang membuka peluang untuk membuka wilayah perkebunan sawit, karet, pertambangandan lain-lain bagi investor baik dari Luar Negeri maupun Dalam Negeri, yang wilayah tersebut sebenarnya adalah merupakan wilayah tanah bathin masyarakat hukum adat. Dengan adanya kebijakan pembukaan lahan tersebut, maka wialyah tanah bathin semakin menepis, bahkan kalau hal ini tidak diantisipasi dengan bijak oleh Pemerintah maka tidak menutup kemungkinan hak atas tanah bahtin akan lenyap.

\section{KESIMPULAN DAN SARAN}

\section{Kesimpulan}

Eksistensi hak ulayat dalam masyarakat hukum adat di provinsi Jambi pada saat ini khususnya di kabupaten Merangin, Kota Sungai penuh dan Kabupaten Bungo sudah mulai melemah. Faktor penyebab melemahnya hak ulayat menjadi hak milik perseorangan adalah, faktor dari masyarakat itusendiri dan faktor kebijakan Pemerintah

\section{Saran}

Agar masyarakat hukum adat dan hak ulayat tetap eksis, maka Pemerintah harus konsekuen mempertahankan dan mengawasi masyarakat hukum adat beserta hak ulayatnya. Selain itu, redaksi Pasal 18B Ayat (2) UUD 1945 sebaiknya diamendemen, jangan diberi peluang kepada masyarakat suatu wilayah untuk tidak mempertahankan masyarakat hukum adat beserta hak ulayatnya. 


\section{DAFTAR PUSTAKA}

\section{Buku}

AP Palindungan, Komentar Atas Undang-Undang Pokok Agraria, Bandar Maju, bandung, 1998

Banbang Daru Nugroho, Hukum Adat (Hak Menguasai Negara Atas Sumber Daya Alam kehutanan dan perlindungan terhadap Masyarakat Hukum adat, PT Reflika Aditia, Bandung, 2015

Supriadi, Hukum Agraria, Cet 6, Sinar Grafika, Jakarta 2015

Sutedi, Adrian, Peralihan Hak Atas Tanah, cet 6, Sinar Grafika, Jakarta, 2014

Setiady, Tolib, Intisari Hukum Adat Indonesia Dalam Kajian Pustaka, Cetakan ketiga, Alfabeta, Jakarta, 2013

Surojo Wignjodipuro, Pengantar dan Azas-azas hukum Adat, Alumni, Bandung, 1978 Saragih, Drajen, Pengantar Hukum Adat Indonesia Edisi II, Tarsito, Bandung,1984

B.Teer Haar, Asas-Asas dan Susunan Hukum Adat, Pradnya Paramita, Jakarta, 1980 Warman, Kurnia, Et Al, Penguatan Tenurial Masyarakat Dalam Penguasaan Hutan, cetakan pertama, ICRAAF Asia Tenggara

\section{Jurnal}

Hayatul Ismi, Pengakuan dan Perlindungan Hukum Hak Masyarakat Adat Atas Tanah Ulayat dalam Upaya Pembaharuan Hukum Nasional, Ilmu Hukum, Volume 2 N0 2 Februari 2012

Nova Yarsina, Perlindungan Hukum Terhadap Tanah Ulayat yang Telah Bersertifikat Di Kota Bukit Tinggi, Jurnal Cendiaka Hukum, 2018

Rosmidah, Pengakuan Hukum Terhadap Hak Ulayat Masyarakat Hukum Adat dan Hambatan Implementasinya, Jurnal Inovatif, Volume No Tahun 2015

Rahmi Justin, Pengakuan hak Ulayat Masyarakat Hukum Adat dalam Pemanfaatan Sumber Daya Air Untuk Penyedian Air Minum di Provinsi Sumatra Barat, 2018 